\title{
Analysis of two cases of potential plumage colour aberrations in the House Sparrow Passer domesticus L., 1758.
}

\section{Análisis de dos casos de posibles aberraciones cromáticas del plumaje en el Gorrión común Passer domesticus L., 1758.}

Maitane Bidasoro $^{1 *}$, Rubén Haro-Gil ${ }^{2}$, Alex Torres-Riera $3,4^{*}$

*

\begin{abstract}
Two cases of possible plumage colour aberrations in the House Sparrow Passer domesticus L., 1758 in Spain are discussed. These two examples highlight the difficulties in correctly identifying plumage colour aberrations in birds. A correct identification of these aberrant individuals as well as information on their number and distribution would certainly expand our understanding of the factors determining their occurrence in natural bird populations.
\end{abstract}

Key words: albininsm, melanism, ino, mutation, pigments, dirt.

\section{Resumen}

Se discuten dos casos de posibles aberraciones cromáticas del plumaje en el Gorrión Común Passer domesticus L., 1758 en España. Estos dos casos evidencian la dificultad que conlleva una buena identificación de las diferentes aberraciones cromáticas del plumaje en aves. Una correcta identificación de las mismas así como conocer el número y la distri-

1 C/ Kaleokerra 11, 1A, Zestoa, 20740, Gipuzkoa.

2 C/ Parlament 34, Amposta, 43870, Tarragona.

3 Asociación Bio+. Av. de América, 64. 7ºB, 28028, Madrid.

4 Department of Evolutionary Biology, Ecology and Environmental Sciences - Institut de Recerca de la Biodiversitat (IRBio), Faculty of Biology, Universitat de Barcelona, Av. Diagonal, 645, 08028 Barcelona.

*Corresponding author: maitane_bidasoro@hotmail.com 
bución de estos ejemplares es fundamental para entender los factores que determinan su aparición en poblaciones naturales de aves.

Palabras clave: albinismo, melanismo, ino, mutación, pigmentos, suciedad.

\section{Laburpena}

Espainian etxe-txolarre Passer domesticus L., 1758 espeziean aurkitutako lumajearen kolore alterazioko bi kasu posible eztabaidatzen dira. Bi kasu hauek agerian uzten dute zein zaila gertatzen den hegaztien lumajean agertzen diren aberrazio kromatiko desberdinak ondo identifikatzea. Horiek behar bezala antzematea eta bai ale horiek zer kopuru eta banaketa duten jakitea oso garrantzitsua da, hegaztien populazio naturaletan ager-tzeko faktore eragileak zein diren ulertu ahal izateko.

Gako hitzak: albinismoa, melanismoa, ino, mutazioa, pigmentuak, zikinkeria.

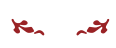

Although there are colours of structural origin, coloration is mainly produced by different pigments: carotenoids, porphyrins and melanins (van Grouw, 2012; CadenaOrtiz et al., 2015). The concentration of these pigments can vary among species and feathers but, any abnormality in each species usual pigmentation patterns is known as a colour aberration (van Grouw, 2012). The main reason for the occurrence of these aberrations are genetic mutations, although other factors such as diet, ageing, oxidative stress, injuries or diseases can also affect feather coloration (Bensch et al., 2000; van Grouw, 2012; Cadena-Ortiz et al., 2015; Izquierdo et al., 2018). The occurrence of genetic mutations can increase for many reasons such as environmental pollution or radiation (Møller y Mousseau, 2001), while inbreeding increases the proportion of individuals expressing these mutations in their phenotype (Bensch et al., 2000). It is believed that, in urbanized areas, the proportion of individuals with colour aberrations increases due to a lower presence of more specialized natural predators (Møller e Ibáñez-Álamo, 2012; Uchida et al., 2016) and a greater availability of resources, which decreases the selection pressures against these individuals (Cadena-Ortiz et al., 2015).

Colour aberrations are not very common in wild vertebrates (Bensch et al., 2000), which is exemplified in the great interest that these individuals generate in the public whenever they are sighted. Within birds, the family Passeridae and specifically the House Sparrow Passer domesticus L., 1758 present one of the highest proportions of aberrant individuals, although this may be mediated by the greater proximity and more intimate association of this species with humans (Sage, 1963). Thus, among bird families, $7 \%$ of albinism and $14 \%$ of melanism cases occur in Passeridae (Sage, 1963). The percentage of individuals of the genus Passer with presence of white feathers 
comprises 1-2\% (del Hoyo et al., 2009); while melanic specimens are less frequent (Sage, 1963; van Grouw, 2012), representing a $0.2 \%$ of all individuals (del Hoyo et al., 2009). Anyway, it should be noted that some authors may not have correctly differentiated the different types of aberrations and, therefore, these data should be taken with caution (van Grouw, pers.com). In this context, the House Sparrow could be an interesting species to understand the abundance of aberrant cases in free-living populations, given its relatively high abundance in urban areas.

Sometimes ornithologists tend to note carefully aberrant individuals (e.g. del Hoyo et al., 2009, Rodríguez-Ruiz et al., 2014; Tinajero, 2014), however more in-depth descriptions of these aberrations are only possible with the live bird in the hand (birdringing sessions) or in museum specimens (e.g. Urcola, 2011; van Grouw, 2012; Cadena-Ortiz et al., 2015). In Spain there are some records of these individuals (e.g. Esteve, 1983; Quesada, 2006) too but, in general, most of them are not systematically recorded and stored, whereas many of them are shared through social networks or appear in magazines as curiosities. Ultimately, most of this potentially-interesting information is eventually lost, suggesting that an online archiving method for recording as accurately as possible the plumage characteristics of each individual could be useful for further analyses. In this note we report two records of colour alterations in the House Sparrow: one specimen with a highly dark (black) plumage and a completely-white individual.

The dark specimen was seen in the province of Lleida, in a service area $\left(41^{\circ} 29^{\prime} 20.5^{\prime \prime} \mathrm{N}\right.$ 051'57.4' $\mathrm{E}$, Catalunya, España) on 17.01.2019. This enclave is bordered by cultivation areas and the nearest town is about $4 \mathrm{~km}$ away (Borges Blanques).

It was a male specimen with a very dark plumage that greatly contrasted with the rest of individuals of the group ( 5 individuals; 2 males and 3 females) (Fig. 1a, b). The head of the individual was completely black (Fig. 1c, d). The ocular region was totally black merging with the rest of the head and the bib (Fig. 1d). In winter, the bib must be diffused, but this specimen exhibited very dark shades that are more typical in summer (Fig. 1d). The chest area had a dark grey tinge with more blackish parts clearing ventrally (Fig. 1d), whereas the cloacal zone and tail was completely black (Fig. 1d). Dorsally, it showed black tones dotted by very dark brown regions (Fig. 1c). The coloration of the head, back and tail seemed to be merged homogeneously (Fig. 1c). Its wings, with clearly darker shades, allowed to glimpse dark brown tones and they clearly marked the typical white wing band of the species (Fig. 1c, d). The bill showed dark grey tones, looking like the common summer coloration, with the commissures a little bit darker (Fig. 1d). Finally, the legs presented a blackish colour (Fig. 1d).

According to the definition given by van Grouw (2012), this specimen may resemble a case of melanism, more specifically a case of eumelanism (van Grouw, 2012, Rodríguez-Ruíz et al., 2017). For an inexperienced observer in coloration, the individual, the individual might not look dirty and the wing band showed its typical white 


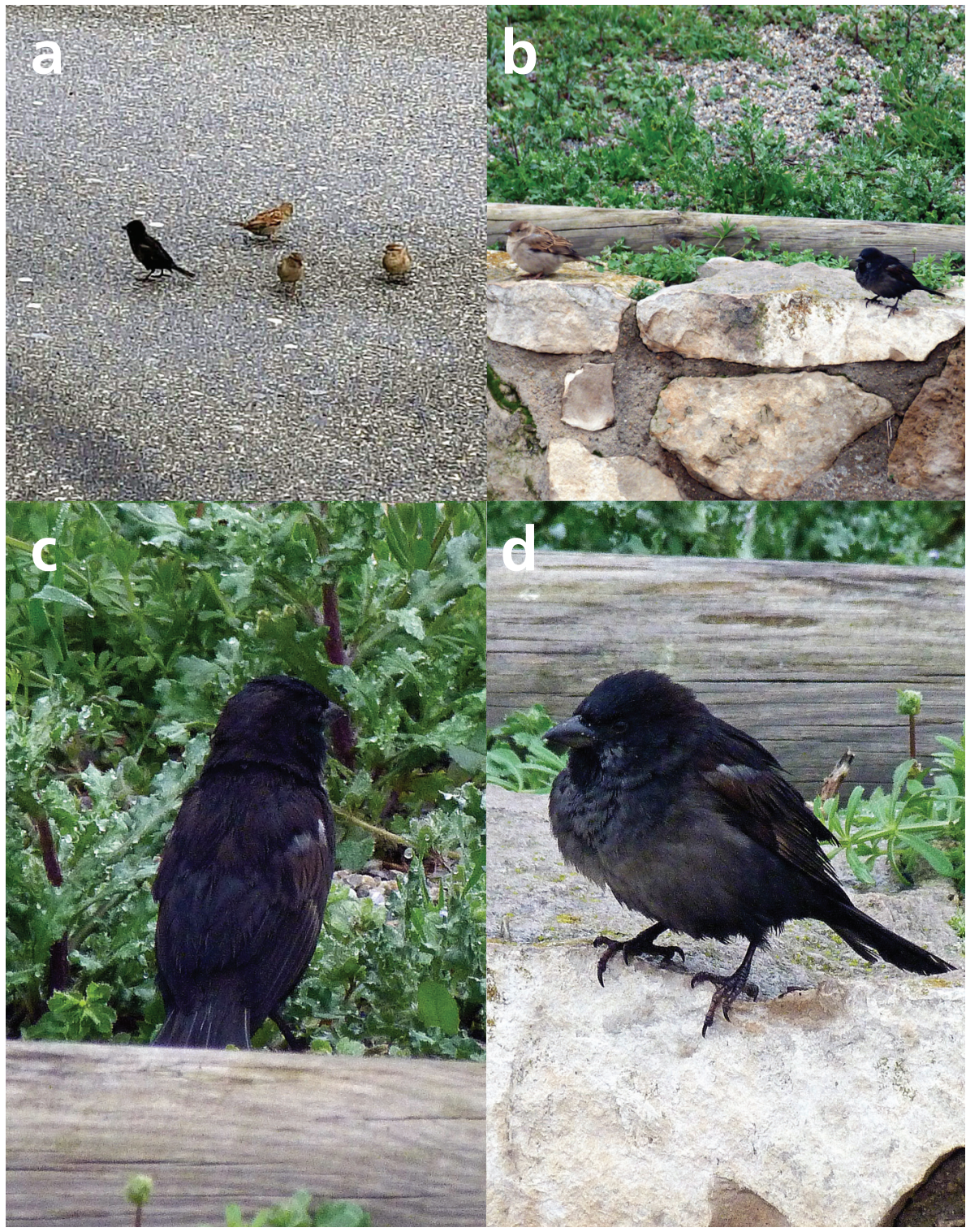

Fig. 1.- a) a male House Sparrow with dark plumage and three females with normal plumage, b) the same black individual and another female with normal coloration, c) dorsal view of the dark individual and d) anterolateral view of the black House Sparrow.

Fig. 1.- a) un gorrión común macho con plumaje oscuro y tres hembras con plumaje normal, b) el mismo individuo negro y otra hembra de coloración normal, c) vista dorsal del individuo oscuro y d) vista anterolateral del gorrión común negro. 
colour (Fig. 1C, d). In addition, the rest of the individuals in the group did not present colour alterations (Fig. 1a). The legs of the bird, however, also showed a dark coloration and, since heritable melanism does not affect the pigmentation of the skin, an external agent (e.g. soot, dust, ash) has to be the cause of this aberration (van Grouw, 2012). Therefore, this is a false positive for melanism, where an individual seems to have a colour aberration that does not really exist.

On the other hand, the individual with whitish coloration was observed in two non-

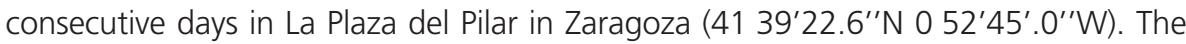
first time it was seen alone (04.10.2018) while, the second time (23.10.2018), it was observed together with other individuals (at least 13 individuals; 7 females and 6 males).

All feathers of this anomalous individual appeared to be white. There was no pigmentation visible in the plumage (Fig. 2) and the eyes had a red tonality (Fig. 2). The tip of the bill had a pinkish tone becoming more yellowish towards the base (Fig. 2). The legs showed a very pale pink hue with white nails (Fig. 2). It was possible to observe that the sixth rectrix on the right was growing (Fig. 2a). This feather showed the same white colour as the other feathers on the body. Considering all these characteristics, this bird resembles an albino individual, but the specimens with the colour aberration ino share many similarities with the albino. Ino individuals with old plumage may have a complete white coloration, but recently-grown feathers usually have a very light cream colour (van Grouw, 2012). Although the growing feather presented by this individual seems to have a similar white coloration to the rest of the plumage (Fig. 2a), the differences could only be seen with the bird in the hand. In very light coloured ino individuals the original light coloured stripe above the eye, which is determined by phaeomelanin, is still visible (van Grouw, pers. com.). This is because phaeomelanin is less affected in ino than eumelanin (van Grouw, 2012). However, the sparrow under study lacks this stripe, so this characteristic does not shed light on whether it is an ino individual or not. Van Grouw (2012) and Cadena-Ortiz et al. (2015) have suggested that albino individuals have low survival prospects in the wild because of their poor vision. Accordingly, white individuals with red eyes in the wild, as the one shown in Figure 2, very likely have the ino colour aberration.

It is worth mentioning that in the same group of this specimen three other individuals were found with several white feathers. The lack of pigments in random feathers is almost always caused by "progressive greying" (van Grouw, 2012) and it would be totally unrelated to ino aberrations.

Recently it has been shown that there is a greater presence of individuals with colour aberrations in urban areas (Izquierdo et al., 2018), which could be associated with environmental alterations, such as chemical pollution increasing mutation rates (Møller y Mousseau, 2001), dietary imbalance (Ruiz et al., 2002; Mennechez y Clergeau, 2006) a lower predation pressure or higher oxidative stress (Izquierdo et al., 2018). However, we still have a limited understanding of how these and other factors affect 

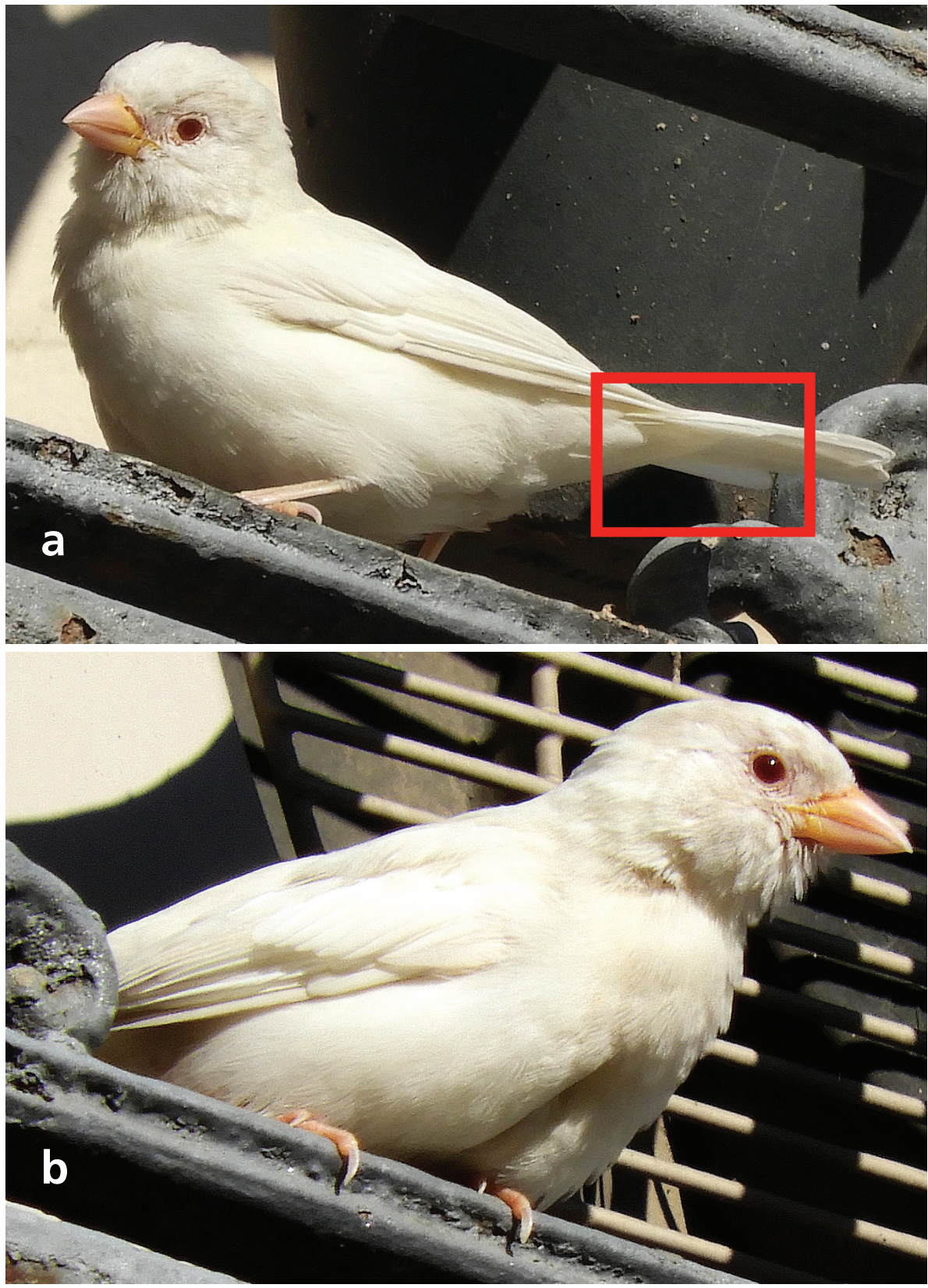

Fig. 2.- A House Sparrow with completely white plumage. a) Framed, the sixth right rectrix in growth.

Fig. 2- Un gorrión común con el plumaje totalmente blanco. a) Encuadrada la sexta rectriz de la derecha en crecimiento. 
the occurrence of colour aberrations. A correct identification of these aberrant individuals would certainly help in this purpose. In this note we encourage ornithologist to document thoroughly their observations and briefly explained some of the difficulties that arise when identifying different colour aberrations, especially when the plumage of these specimens cannot be closely analysed.

\section{Acknowledgements}

We would like to thank Pedro J. Cordero-Tapia (University of Castilla-La Mancha), Carles Senar (Museum of Natural Sciences of Barcelona) and José Domingo RodríguezTeijeiro (University of Barcelona) for their advice and help so that this article could be published. We are grateful to Hein van Grouw for the technical advice and review of the manuscript.

\section{Bibliography}

Bensch, S., Hansson, B., Hasselquist, D., Nielsen, B., 2000. Partial albinism in a semi-isolated population of great reed warblers. Hereditas 133, 167- 170.

Cadena-Ortiz, H.F., Bahamonde-Vinueza, D., Cisneros-Heredia, D.F., Buitrón-Jurado, G. 2015. Alteraciones de coloración en el plumaje de aves silvestres del Ecuador. Avances en Ciencias e Ingenierias 7(2), B75-B90. Disponibe en: https://pdfs.semanticscholar.org/a2c0/91d36a7399abb2f2df6472e360b3c2a0f569.pdf

Del Hoyo, J., Elliot, A., Sargatal, J., 2009. Handbook of the Birds of the World, Bush-shrikes to Old World Sparrows, vol. 14. Lynx Edicions, Barcelona.

Esteve, E., 1983. Pardal (Passer domesticus) amb albinisme parcial. ICO. 3.2: 31.

Izquierdo, L., Thomson, R.L., Aguirre, J.I., Díez-Fernández, A., Faivre, B., Figuerola, J., Ibáñez-Álamo, J.D., 2018. Factors associated with leucism in the common blackbird Turdus merula. J. Avian Biol. 49(9), e01778.

Mennechez, G., Clergeau, P., 2006. Effect of urbanisation on habitat generalists: starlings not so flexible? Acta Oecol. 30(2), 182-191.

Møller, A.P., Ibáñez-Álamo, J.D., 2012. Escape behaviour of birds provides evidence of predation being involved in urbanization. Anim. Behav. 84(2), 341-348.

Møller, A.P., Mousseau, T.A., 2001. Albinism and phenotype of barn swallows (Hirundo rustica) from Chernobyl. Evolution 55(10), 2097-2104.

Quesada, J., 2006. Different pigmentary alterations of a carotenoid-based patch in the Great Tit Parus major: two cases to discuss. ICO 22, 9-13. 
Rodríguez-Ruíz, E.R., Poot-Poot, W.A., Ruíz-Salazar, R., Treviño-Carreón, J., 2017. Nuevos registros de aves con anormalidad pigmentaria en México y propuesta de clave dicotómica para la identificación de casos. Huitzil 18(1), 57-70.

Rodríguez-Ruiz, E.R., Valencia-Herverth, J., Garza-Torres, H.A., Aguilar-Pérez, C., LópezMoctezuma, L., 2014. Partial leucism in the house sparrow Passer domesticus (Passeriformes: Passeridae) in Mexico. Acta Zool. Mex. 30(3), 692-695.

Ruiz, G., Rosenmann, M., Novoa, F.F., Sabat, P., 2002. Hematological parameters and stress index in rufous-collared sparrows dwelling in urban environments. Condor. 104 (1), $162-$ 166.

Sage, B.L., 1963. The incidence of albinism and melanism in British birds. Br. Birds. 56(11), 409-416.

Tinajero, R., Rodríguez Estrella, R., 2014. Partial albino house sparrows (Passer domesticus) in Baja California Sur, Mexico. Acta Zool. Mex. 30(3), 742-745.

Uchida, K., Suzuki, K., Shimamoto, T., Yanagawa, H., Koizumi, I., 2016. Seasonal variation of flight initiation distance in Eurasian red squirrels in urban versus rural habitat. J. Zool. 298(3), 225-231.

Urcola, M., 2011. Aberraciones cromáticas en aves de la colección ornitológica del Museo Argentino de Ciencias Naturales "Bernardino Rivadavia". Rev. Mus. Argent. Cienc. Nat. nueva serie 13(2), 221-228.

Van Grouw, H., 2012. What colour is that sparrow? A case study: colour aberrations in the house sparrow Passer domesticus. Intern. Stud. Sparrows 36(1), 30-55.

Fecha de recepción/ Date of reception: 20/12/2019

Fecha de aceptación / Date of acceptance: 23/05/2020

Editor Asociado / Associate editor: Iván de la Hera 